\title{
The problem of credible commitment in reconstruction*
}

\author{
CHRISTOPHER J. COYNE* \\ Department of Economics, West Virginia University, USA \\ PETER J. BOETTKE** \\ Department of Economics, George Mason University, Fairfax, VA, USA
}

\begin{abstract}
Reconstruction involves military occupation with the aim of rebuilding and reforming both formal and informal institutions along liberal democratic lines. We contend that successful reconstructions require mechanisms that make reforms credible over the long run. In the absence of a signal of sustained credible commitment, institutional reforms will not be trusted by the populace resulting in the failure of the broader reconstruction. The incentive and epistemic aspects of the credible commitment problem are analyzed. We also consider potential solutions to the problem of credible commitment. Absent such solutions, attempts to 'export' institutions via military occupation will fail or produce dysfunctional outcomes. An analysis of the numerous aspects of the credibility problem in the current reconstruction of Iraq is provided to illuminate the central arguments.
\end{abstract}

\section{Introduction}

To what extent can foreign occupiers export the foundations of liberal democratic, economic, and social institutions where they do not already exist? ${ }^{1}$ This is the central question surrounding the viability of foreign reconstruction efforts. Reconstruction involves military occupation with the aim of rebuilding and reforming both formal and informal institutions along liberal democratic

\footnotetext{
*Email: chris.coyne@mail.wvu.edu

**Email: pboettke@gmu.edu

We would like to thank three anonymous referees and the editors for their useful comments and suggestions. Earlier versions of this paper were presented at the Southern Economics Association Conference, New Orleans, LA, November 19-21, 2007 and The Public Choice Society Meetings, San Antonio, TX, March 6-9, 2008.

1 'Institutions are the rules of the game in a society or, more formally, are the humanly devised constraints that shape human interaction' (North, 1990: 3). More specifically, we consider institutions to include the rules and norms that individuals follow in their daily lives, the formal (e.g., state-made constitutions, codified laws, legislation, and so on) and informal (e.g., norms, conventions, and what is generally referred to as culture) constraints and their enforcement characteristics. There is a large literature establishing the 'primacy of institutions' for economic progress and development (see Acemoglu et al., 2001, 2002; Acemoglu and Johnson, 2005; North, 1990; Rodrik et al., 2004). Our goal in this paper is to understand the ability of foreign occupiers to establish institutions conducive to liberal democracy and economic development where they do not exist or where they are dysfunctional.
} 
lines. ${ }^{2}$ In addition to the restoration of physical infrastructure and social services, a critical element of reconstruction entails structural reform in the economic, legal, political, social, and security sectors. As the historical record indicates, efforts to export liberal democracy via military reconstruction have resulted in more failures than successes (see Coyne, 2008a; Payne, 2006). ${ }^{3}$ Understanding why this is the case is critical not only for current reconstruction efforts, but also for understanding the feasibility of future efforts as well.

For the most part, research regarding foreign reconstruction efforts has been limited to the disciplines of history, political science, and public policy (see for instance Fukuyama, 2004, 2005). Economists have only recently turned their attention to the political economy of reconstruction. Foote et al. (2004) focus on the viability of economic reforms in Iraq following the 2003 invasion and occupation. They describe the Coalition's attempt to reform Iraq's economy and discuss several issues, including security and violence, which will influence the ultimate outcome of these reform efforts. Kofford (2003) explores the public choice aspects of the 2003 invasion of Iraq, while Kurrild-Klitgaard (2004) utilizes the tools of public choice to explore the constitutional dilemma facing Iraq in the post-war period. Cowen and Coyne (2005) provide a game theoretic framework for understanding the general reconstruction process. They contend that success in reconstruction entails finding mechanisms that raise the relative payoff to engaging in continued cooperation around liberal institutions as compared to continued conflict. Coyne (2008a) builds on this earlier work and develops an 'economics of reconstruction' which considers the specific mechanisms that contribute to the transformation of situations of conflict to cooperation. Coyne (2008b) explores the economics of bureaucracy in the context of reconstruction. He concludes that the information, incentive, and knowledge problems faced by bureaucracies constrain the ability of foreign occupiers to exogenously impose liberal democratic institutions in foreign countries. Stiglitz and Bilmes (2008) provide an estimate of the total costs of the most current Iraq conflict and reconstruction. They conclude that in contrast to initial estimates, the total costs of the entire effort in Iraq could reach $\$ 3$ trillion. Myerson (2007) explores the theories and notions of nation building implied in the writings of L. Paul Bremer and the US Army and Marine Corps.

2 On the various motivations behind foreign interventions, see Peceny (1999).

3 There is no consensus regarding the definition of 'success' in reconstruction efforts. Coyne (2008a) relies on the Polity Index and proposes a Polity Score of +4 as a benchmark of success. He considers the Polity Score of the reconstructed country 5, 10, and 15 years after the end of occupation to gauge success or failure. Payne (2006) analyzes the political history of countries after troop withdrawal. In judging each effort as a success or failure, he focuses on events associated with the collapse of democratic rule, including the suppression of political opposition, infringements on freedom of speech, violent transfers of power, and civil war. Although each of these authors relies on a different benchmark of success, both find more failures than successes. 
Focusing on the current reconstruction of Iraq, he emphasizes that the building blocks of a state are found in the reputations of its political leaders.

We seek to contribute to this existing literature by focusing on the importance of credible commitment in reconstruction efforts. While the existing literature on reconstruction recognizes the importance of constraints - economic, legal, political, and social - for sustainable reforms, we provide a detailed analysis of the importance of credibility for successful reform and reconstruction. Our central thesis is that successful reconstructions require mechanisms and institutions that make reforms credible over the long run. While resources (e.g., troop levels, monetary and humanitarian aid, and so on) and planning are indeed important, reforms will be ineffective without rules binding politicians and bureaucrats in future periods. ${ }^{4}$ The logic here is straightforward. In the absence of mechanisms that signal sustained credible commitment, institutional reforms will not be trusted by the populace resulting in their ultimate failure. Given that reforms aimed at changing economic, legal, political, and social institutions are central to any reconstruction, their acceptance and sustainability are critical for success.

We are cognizant of the fact that a wide variety of variables influences the ultimate outcome of reconstruction efforts. However, focusing on credibility and commitment problems allows us to highlight a central dilemma that must be overcome for ultimate success. Absent a solution to the problem of credible commitment, reconstruction will fail even if those efforts are characterized by thorough planning and adequate resources. As Myerson (2007) notes, success in creating the sustainable foundations of a state requires opportunities for political leaders to develop reputations for responsible governance. Success in this regard ultimately requires 'breaking from the past' and credibly committing to future behaviors.

Our analysis focuses on two aspects of the credible commitment problem in the context of efforts to exogenously impose institutions. The first aspect is the issue of incentives. Policymakers must have the incentive to 'do the right things' to bring the desired reforms about. The second is the epistemic aspect of reforms. The fact that reconstruction efforts involve occupation by 'alien' military forces adds an additional wrinkle to the traditional credible commitment problem. In addition to ensuring that the proper incentives are in place, occupiers must deal with the fact that the reform process is embedded within an existing cultural context. The adaptive efficiency of a social system is a function of the epistemic properties of its political, legal, economic, and customary traditions and institutions (see North, 2005; Boettke et al., 2008). As such, reforms must be grounded in customary practices and institutions. Because

4 North (1993) contends that a central question that remains unanswered is how successful economies have developed institutions that produce the credible commitment that facilitate complex contracts and interactions. 
occupiers are outside the indigenous context of the country being reconstructed, they will often perceive and interpret the credible commitment problem in a different manner than indigenous citizens. A successful reconstruction requires finding adequate solutions to both aspects of the credible commitment problem.

We proceed in the following manner. In the next section, we provide a discussion of the problem of credible commitment in adopting reforms. We provide a game theoretic illustration of the fundamental credible commitment problem and discuss the connection to the existing literature on the issue of credibility and sustainable reforms. Section 3 provides an application of the problem of credibility in the context of reconstruction. Specifically, we consider the ongoing efforts to exogenously implement economic, political, and social institutional reforms in Iraq. Particular focus is placed on the complex array of simultaneous 'games' being played. It is our contention that reforms have failed to take hold because of the absence of mechanisms to signal credibility. Section 4 considers some potential solutions to the problem of credible commitment involved in reconstruction efforts. Section 5 concludes with the implications of our analysis.

\section{The problem of credible commitment in institutional reform}

Commitment problems are present in all areas of life. Most economic, political, and social interactions are characterized by some temporal dimension. Individuals involved in these interactions must be confident that agreements made in the present will be binding in future periods. To understand this, consider a basic exchange involving credit. The creditor delivers a good or service in the present with payment to be made by the creditee in a future period. The issue is that when the future date arrives, it may not be in the creditee's interest to make the previously agreed upon payment. If this is indeed the case, payment fails to be made and the agreement breaks down. If the creditor realizes this possibility at the time of the initial agreement, he may refuse to enter into the exchange. Similar logic can be extended to a wide array of interactions (e.g., political, social, and so on) beyond basic economic transactions. In many cases, solutions (e.g., enforceable contracts, repeated interactions, third-party agencies, and so on) to the problem of credibility have emerged which provide incentives for parties to deliver on their agreements and promises.

However, it cannot simply be assumed that such solutions will emerge. Where adequate solutions to the commitment problem are lacking, agreements may unravel. This is a central issue in reconstruction efforts which attempt to create sustainable agreement around reforms. Reforms are agreements to change behaviors in future periods. In order for the reform to be effective, parties to the agreement must have the incentive to deliver instead of reneging on their promise. Reforms that fail to appreciate the importance of incentives for directing action are doomed to fail because they neglect the importance of signaling a credible commitment. 
The recognition of the temporal disconnect between choices today and choices tomorrow is critical to creating viable institutions and reforms (see Klein, 1990). Perhaps most important is the problem that arises when we consider the strategic interaction between policymakers (i.e., reformers) and citizens. From the viewpoint of policymakers, a reform that seemed optimal when it was first introduced may appear inferior in subsequent periods. Without a binding commitment to the reform that is credible, policymakers may have an incentive to renege on the initial policy and shift to the policy that appears optimal in the current period. As Acemoglu and Robinson (2006: 133, emphasis original) note, 'commitment problems arise when political power is not in the hands of the beneficiaries of the promised policies. In essence, those with political power cannot commit not to use it to renege on the promises made in the past.' Credibility becomes an issue when there is a disjoint between those holding power and the beneficiaries of announced reforms.

For example, citizens may benefit from certain reforms, but members of the political elite incur the cost of those reforms in terms of reduced power, income, or discretion. Under such circumstances, it may be in the interest of policymakers to make a commitment to reform and then renege on that promise in future periods so that they can maintain their hold on power, discretion, or higher levels of income. Anticipating this behavior on the part of policymakers, citizens must be confident that the political elite will deliver on their initial promise in order to buy into the reform.

This logic is central to reconstruction efforts. To provide one example, certain groups may agree to power sharing agreements while occupiers are present, only to later renege once occupiers have exited (see for example Roeder and Rothchild, 2005; Hartzell and Hoodie, 2007). In this case, the absence of a credible commitment leads to the unraveling of previous agreements and the potential breakdown of the reconstruction effort.

The problem surrounding the sustainability of reforms arises because citizens realize the incentives facing policymakers. Stated differently, citizens will anticipate that policymakers will have an incentive to shift their behavior over time. As Kydland and Prescott (1977) emphasize, current decisions by actors depend critically on expectations regarding future policy and those expectations are influenced by current and past policies chosen. Policy decisions and social rules create expectations, and expectations guide actions. Absent a binding constraint, past promises by policymakers may very well be broken in the present or future. Given this potential, citizens will fail to commit to the initial reform, which will fail to take hold and to be effective.

We can illustrate the policy dilemma described above in terms of a basic game. Consider a game of complete and perfect information as illustrated in Figure 1, where Player 1 is the policymaker and Player 2 is the representative citizen, which includes all individuals other than the policymaker/reformer. The game begins when the government policymaker announces a reform. This could be any type 
Figure 1. The commitment problem

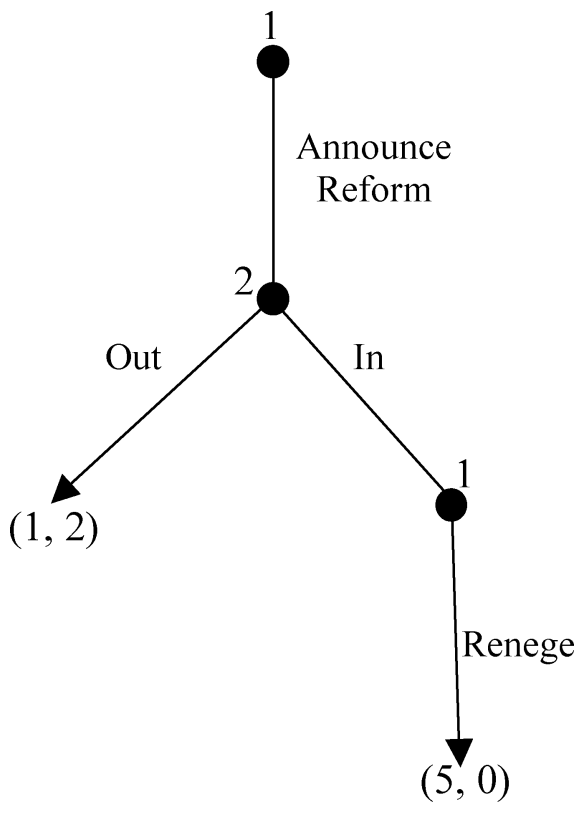

of reform from a basic policy announcement to a more complex change in the structure of formal institutions. The citizen, who chooses second, must decide to either enter the game by accepting the reform or stay out of the game by refusing to accept and commit to the announced reform. The issue is that if the citizen does decide to enter the game, the policymaker can benefit from reneging on the initial reform announcement in future periods. Since the citizen knows the sequentially rational move of the policymaker, they choose the only viable option - staying 'out' of the announced reform. In the absence of a credible commitment on the part of policymakers to tie their own hands, the reform will stall.

The unique Nash equilibrium of this game is for the government to renege on the announced reform and for the citizen to stay out (Renege, Out). The reform fails to get off the ground as the citizen anticipates that the policymaker will ultimately renege on their initial promise.

In reality, the actual commitment problem is more complicated than that illustrated in Figure 1. There is the additional problem that the citizen cannot actually know if the policymaker is sincere or insincere in their policy announcement. The logic of the game is basically the same as that illustrated in Figure 1, but this game is now characterized by complete and imperfect information. Policymakers (Player 1), who can be either sincere or insincere, announce a reform. The citizen (Player 2) must decide whether to accept ('In') or reject ('Out') the reform. The major issue facing the citizen is that they cannot 
Figure 2. The commitment problem with imperfect information

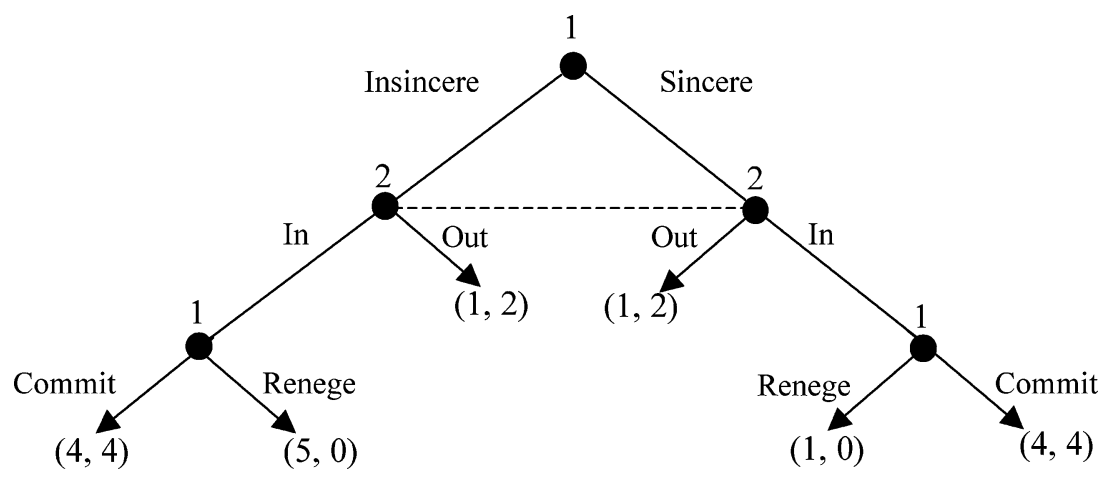

know whether the policymaker is being sincere or insincere in their reform announcement. The citizen's only information concerning the policymaker is their past policy history. The announced reform is intended to break from the past, but the citizen bases their expectation of the policymaker's behavior on past policy decisions. If the citizen decides to accept the reform, the policymaker must then decide whether to commit to the reform in future periods or renege on the announced policy. This game is illustrated in Figure 2.

If the policymaker is 'insincere' in the announced reform, the citizen's best strategy is to stay out and not accept the reform. If the citizen were to stay in and accept the reform, the insincere policymaker would renege in future periods. In contrast, if the policymaker is 'sincere' in their commitment to the announced reform, the best strategy for the citizen is to enter the game and accept the reform as credible. In this case, the citizen accepts the reform and the policymaker commits to the reform in future periods. The reform will be self-sustaining over time and leads to sustainable change. Further, given that the policymaker is sincere, the reform yields a higher payoff for both parties as compared to if the citizen had stayed out or if the policymaker had reneged on the announced reform.

Given that the citizen possesses imperfect information as to the policymaker's true type, and given certain probabilities derived from previous experiences with the policymaker, it may very well be rational for the citizen to assume that the policymaker will be insincere in their announced commitment to reform. The only way out of this dilemma is to establish a commitment to reform that is binding and credible. This is easier said than done.

The problem is not simply a matter of establishing constraints on the activities of policymakers. To initiate reforms, policymakers must simultaneously establish constraints and send a strong signal to citizens that they are sincere in their commitment to reform. For example, during war a commanding officer whose troops have crossed a river to engage in battle may order that the bridge be burned to signal a credible commitment to stand and fight. Reforming policymakers must 
take similar steps to signal a credible and binding constraint to the announced reform. Once a credible signal is sent, it can create sustainable change based on the repeated dealings between policymakers and citizens. ${ }^{5}$

The importance of credible commitment for political outcomes is recognized in the existing literature. For example, Boettke $(1993,2001)$ explores how the absence of credible commitments contributed to the failure of reforms in the former Soviet Union. Persson and Tabellini (2000) show that the effects of institutional changes vary from society to society depending on the ability to make credible political promises prior to elections. Kydd and Walter (2002) explore the role of extremists in sabotaging the process of peace negotiations. They conclude that extremists are successful in this regard when they are able to foster mistrust and uncertainty regarding the credibility of those involved in negotiating and implementing the peace deal. Keefer and Vlaciu (2005) explore how different policy choices across democracies can be explained by the ability of political competitors to make credible commitments to voters in the pre-election period. In their economic analysis of dictatorship and democracy, Acemoglu and Robinson (2006: 133-172) analyze the importance of credible commitment in the distribution of political power. Keefer (2007) argues that where political leaders lack credibility, they are less able to prevent rebellion because they cannot make binding promises to potential insurgents. Similarly, Flores and Nooruddin (2007) contend that the key to economic recovery in post-conflict societies is a credible commitment to peace. The underlying logic is that absent such a commitment, individuals will fail to make the investments necessary for economic recovery and development. In their evaluation of World Bank assistance programs to post-conflict societies, Nooruddin and Flores (2008) contend that the central obstacle to achieving peace among combatants is securing credible commitments. Gehlbach and Keefer (2008) explore how autocracies and weak democracies use institutionalized ruling parties to signal credibility to potential investors. Absent the protections offered to investors under a mature democracy, members of the political elite may invest in sending a credible signal that they will not expropriate the property of investors.

Understanding the issues associated with credibility and commitment in the context of reform goes a long way in illustrating a central dilemma in reconstruction efforts. These efforts rely on foreign occupation to generate institutional reform. As such, success in reconstruction efforts, just as in any other reform effort, requires mechanisms that signal a binding commitment on the part of the political elite to abide by the announced reform in future periods.

Our discussion of the problem of credible commitment emphasizes the importance of ensuring that reforms are viewed as binding and legitimate. In reality, the reforms in reconstruction efforts are often more complex because the 'policymaker' in question is some combination of various indigenous political 
elites and exogenous occupiers and policymakers who oversee the reconstruction of institutions. In such cases, citizens must judge the credibility and commitment of not only indigenous actors, but also of exogenous actors as well. For example, in the case of Iraq, citizens must decipher the credibility of the leaders of various indigenous ethnic and religious groups as well as that of the occupiers. As will be discussed, the difficulty in adequately deciphering and interpreting this credibility has been a major barrier to the broader reconstruction effort in Iraq.

The recognition of the multiple layers of indigenous and exogenous actors involved in reconstruction efforts highlights an important point. In addition to the standard incentive issue discussed above, there is also an epistemic aspect to the problem of credible commitment. First, policymakers must have the incentive to keep their promises made in earlier periods. The epistemic aspect of the commitment problem arises because in the context of reconstruction, credible commitment games are embedded within a cultural context (see Coyne, 2008a). This means that different players will interpret the issue of credibility in different ways, which makes finding a solution that much more difficult. For example, what indigenous citizens view as a signal of credibility may be fundamentally different from what exogenous occupiers view as legitimate and binding. Reforms that fail to appreciate this epistemic context will fail to 'stick' over time (see Boettke et al., 2008).

In sum, while the issue of incentives deals with the structure of the game, the epistemic aspect deals with how different players interpret the game. Exogenous occupiers and policymakers will often interpret and understand the credible commitment problem in a different manner than indigenous citizens. Differences in interpretation can occur through several channels, including a misunderstanding of the fundamental commitment problem, a misunderstanding of the overtures necessary to signal credibility, or a misunderstanding of the signals being sent by indigenous citizens. Where such misinterpretations occur, it can result in the failure to signal credibility and the ultimate failure of institutional reforms. The ongoing occupation and reconstruction of Iraq illustrates the various aspects of the credible commitment problem as well as the resulting difficulties for the broader reform process.

\section{The problem of credible commitment in the reconstruction of Iraq}

\subsection{Background of the occupation and reform program}

The Coalition Provisional Authority (CPA) was established on 21 April 2003, a month after the invasion if Iraq. ${ }^{6}$ On 11 May 2003, L. Paul Bremer was named chief executive of the CPA. In this role, Bremer was responsible for

6 The CPA was preceded by the Office of Reconstruction and Humanitarian Assistance (ORHA). The purpose of the ORHA was to serve as an interim caretaker of Iraq until a democratically elected government could be established. 
overseeing the occupation of Iraq. This included reforming Iraq's economic, social, and political institutions. Economic reforms were to be based on 'free market' principles, including privatization, reduced government intervention, and openness to foreign investment and trade (King, 2003). These reforms were introduced in the form of 100 orders that were issued by the CPA under Bremer's leadership. According to the CPA, these orders 'are binding instructions or directives to the Iraqi people that create penal consequences or have a direct bearing on the way Iraqis are regulated, including changes to Iraqi law'.7

The CPA orders covered a wide range of issues and activities. For example, Order 1 declared the 'De-Ba athification of Iraqi Society', while Order 2 dissolved the Iraqi army and intelligence service. Order 39 called for the privatization of Iraqi state enterprises, while Order 40 opened the previously state-run banking system to foreign banks. Order 49 reduced the tax rate on Iraqi corporations from $40 \%$ to a flat rate of $15 \%$. Order 12 suspended all tariffs, duties, taxes, and surcharges for goods imported or exported from Iraq.

In addition to the 100 orders issued by the CPA, Bremer had a distinct vision of how reformed political, legal, and social institutions in Iraq should look. Myerson (2007) notes that Bremer's vision of the new Iraq was grounded in the development of a national constitution that would not only establish checks and balances, but also clearly establish rights for individuals and minority groups. Moreover, Bremer's vision called for a professional police force that would enforce the rules set forth by the constitution. The police force was to be subject to the rule of law, meaning that it was to be governed by the same laws as all other Iraqi citizens. Bremer appointed a council - the Iraqi Governing Council to draft a provisional constitution known as the transitional administrative law. ${ }^{8}$ The transitional law remained in effect until the permanent constitution was approved in October 2005.

To date, the institutional reforms implemented by Bremer and the CPA have failed to have the desired effect. Political and social institutions remain fragile and unpredictable. Continued violence by insurgents has contributed to the general instability. The Iraqi economy has struggled to recover following the invasion and war. For example, a 2006 report by the World Bank emphasized that 'oil production and exports have yet to reach prewar levels, and non-oil sectors remain sluggish. High unemployment, poverty, and weak social protection systems dominate public concerns and threaten the fragile democracy' (1). The report also noted that $8-10 \%$ of the Iraqi population was living in absolute poverty, while another $12-15 \%$ of the population was vulnerable to falling into

7 Source of quote, CPA official website: http://www.cpa-iraq.org/regulations/.

8 The Iraqi Governing Council served as the government of Iraq from July 2003 to June 2004. In June 2004, sovereignty was transferred to the Iraqi Interim Government, which was replaced by the Iraqi Transitional Government in May 2005. The Iraqi Transitional Government was replaced by the first permanent government of Iraq in May 2006. 
that category. Of course, much of the economic devastation can be attributed to the command economy under the Hussein regime as well as the war itself (see Crocker, 2004). Nonetheless, the reform orders passed by the CPA have failed to generate the economic turnaround that many predicted and Bremer's vision of Iraq's reconstructed political, legal, and social institutions has failed to take hold. The central question is: Why has the US failed to effectively reform Iraq's institutions?

It is our contention that the issue in Iraq has not been the nature of the reforms per se, but rather the failure to effectively signal credibility. More specifically, the failure of reforms in Iraq is due to the inability of occupiers to establish a credible commitment so that Iraqi citizens view the reforms as binding. Instead, many Iraqi citizens expect policymakers to renege on promises in future periods. In the context of the games depicted in the previous section (Figures 1 and 2), the 'policymakers' in Iraq consist of the foreign occupiers and foreign political elite as well as the indigenous political elite who influence the specifics of the reforms implemented. The 'citizens' refer to all other Iraqi citizens as well as other foreigners (e.g., foreign investors, business people, and so on) who are not policymakers. As depicted in these games, the citizens must decide to 'buy in' or 'stay out' of the proposed reforms. In the latter case, the reforms fail to get off the ground and will not sustain over time. To date, this has been the most common outcome in Iraq. To understand why this has been the case, we consider the myriad games and players involved in the current reconstruction of Iraq, which can be summarized as follows:

\section{Games}

(a) Military game: Policymakers are attempting to reduce violence, establish peace, and secure local support against the insurgency. A key aspect of this process entails training an effective Iraqi police and military force.

(b) Economic game: Policymakers are attempting to establish the parameters of a liberal economy (e.g., property rights, sound currency, free movement of goods, labor, capital, and so on) in order to increase investment and establish the foundations for economic development.

(c) Political and social game: Policymakers are attempting to foster liberal democratic institutions, which are inclusive in nature and protect individual, civil, political, and religious rights. Critical to this game is the process of reconciliation as well as the establishment of the rule of law and other constraints on government behavior.

\section{Policymakers}

(a) The Multi-National Force: Led by the United States, the coalition of occupiers oversees the entire Iraq occupation and reconstruction effort. The coalition faces issues of credibility with the indigenous Iraq populace due largely to historical interactions and interventions directly in Iraq as well as in the broader region. 
(b) The US political elite: The US political elite consist of leaders and policymakers who have the power to shape the outcome in Iraq. This includes the executive and legislative branches as well as the numerous government bureaus and agencies involved in the reconstruction effort.

(c) The Iraqi political elite: The Iraqi political elite consist of national and local leaders who can influence the ultimate outcome of the broader reconstruction effort. Credibility issues among the political elite are largely due to a lack of trust stemming from historical interactions with other indigenous individuals and groups.

(d) Foreign governments: Iraq's neighbors (i.e., Iran, Jordan, Saudi Arabia, Syria, and Turkey) do not directly 'make policy' in Iraq, but they play a key role in the reconstruction. For example, the government of Iran has indirectly influenced the reconstruction with monetary and military aid to certain groups. Further, these governments will be key players when occupiers exit the country since they have the ability to undermine the institutional reforms carried out during the reconstruction.

\section{Citizens}

(a) Iraqis: This group consists of private Iraqi citizens who are not part of the political elite. Most Iraqi citizens are involved in numerous overlapping 'nested' games with a variety of groups and sub-groups at different levels, resulting in a complex dynamic. Citizens must decide whether to 'buy in' to reforms associated with the reconstruction effort or to 'stay out' and not support the reforms. In general, Iraqi citizens must decide if they feel confident that investments they make in the reconciliation process, as well as in economic, political, and social reforms will be beneficial and sustainable over time.

(b) Foreigners: This group consists of all other individuals who are not part of the 'policymaker' category and who are not Iraqi citizens. Like Iraqi citizens, these individuals must decide whether or not to invest in the reconstructed country.

In what follows we consider the various aspects of the Iraqi reconstruction in more detail with particular focus on the specific reasons that the credible commitment problem persists and why reforms have failed.

\subsection{Indigenous divisions}

The most significant barrier to overcoming the problem of credible commitment is Iraq's deep ethnic and religious differences. Successful reforms must satisfy members of Iraq's major ethnic groups - the Arabs and Kurds - and religious groups - the Shi'a and Sunni Muslims. Given the historical experiences and interactions of the members of these groups, this is a monumental task.

To better understand these divisions, consider that while most of the Iraqi Kurds follow the religion of Sunni Islam, as do approximately one-fifth of the total Iraqi population, they possess their own unique cultural practices and use their own language. The result is that the Sunni Kurds have their own identity 
separate from the rest of the Sunnis in the country. Iraqi Kurds were violently repressed under the Hussein regime, but they experienced autonomy with the protection of the US military following the end of the first Gulf War. Given this history, Kurds are skeptical of the Sunni minority, who controlled the country during the Hussein era, and are concerned about the possibility of losing their independence in the post-Hussein Iraq that is currently evolving. Like the Kurds, the Arab Shi'a, who comprise approximately $60 \%$ of the Iraqi population, were violently victimized by the Sunni minority prior to the collapse of the Hussein government. In addition to violent repression, the Shi'a-dominated cities in Iraq, especially those in the southern region, suffered from a lack of investment and development under the Hussein regime. The historical experiences and interactions of the members of these groups has created a set of tensions that make the possibility of credible reforms at the national level extremely difficult, if not impossible, over the short run (see Anderson and Stansfield, 2004; Baker and Hamilton, 2006: 13-19).

The tensions in Iraq go beyond the major religious and ethnic groups discussed above. In addition to the issues with inter-group interactions, there are also intragroup tensions that create problems for reforms. For example, there are various intra-group factions in the broader Sunni and Shi'a groups in Iraq at both the national and local levels. Further, Shi'a political leaders are divided into at least four major sub-parties and there are factions within those sub-parties (see Fearon, 2007: 10).

As another example, consider that Muqtada al-Sadr, a Shi'a cleric, and Ayatollah Ali Sistani, a well-respected Shi'a authority in Iraq, both have varying levels of control and influence over different parts of the broader Shi'a group. The ability of each of these individuals to influence the legitimacy and success of the Iraqi reconstruction are evident. For example, early in the reconstruction (20032004), al-Sadr utilized anti-Americanism to rally his militia and violently fight the occupiers. More recently, al-Sadr has used his position of power to negotiate local ceasefire agreements, which have aided the reconstruction process. Ali Sistani resisted initial attempts to establish a transitional parliament in 2004 because it was not directly elected (Diamond, 2004: 48). Similar to the Shi'a, the Sunnis are characterized by a similar array of sub-groups throughout Iraq. Putting aside the issue of inter-group coordination, these various intra-group layers make widespread and credible cooperation within each ethnic and religious group extremely costly.

Given the long history of conflict and tensions both within and between these groups and sub-groups, why would each group view the claims of the others as credible? Further, even if the various groups and sub-groups are sincere in their claims, enforcement mechanisms are lacking. Currently the US is the main enforcer of agreements struck between the parties, but the length of the occupation is unclear resulting in uncertainty regarding the future stability of agreements reached in the current period. The problem is that indigenous actors 
cannot determine the extent to which any agreement is credible absent the provision of enforcement by the third-party occupiers. To the degree that Iraqis believe that the sustainability of agreements is due to enforcement by military occupiers, they are unlikely to accept reforms as being credible and binding in future periods.

The inability to bargain toward a mutually agreeable outcome has contributed to the ongoing insurgency and security issues that plague Iraq (Diamond, 2004). As Keefer (2007) indicates, when political leaders lack credibility, they cannot make binding promises to potential insurgents. The absence of credibility makes the likelihood of continued insurgency that much more likely. This, in turn, further contributes to the inability of occupiers to carry out other aspects of the reconstruction such as building infrastructure and facilities.

\subsection{The dynamics of alien rule}

The potential for overcoming the problem of credible commitment becomes even more complex when one considers the role of foreign occupiers. In addition to the interactions between the groups and sub-groups within Iraq, these same groups also interact with the occupiers. In addition to expectations regarding how other indigenous groups will act, those in Iraq also have expectations regarding the actions of the occupiers. Most Iraqis view the military occupiers as 'alien rulers' instead of liberators committed to Iraqi self-determination. For example, a CNN/USA Today/Gallup Poll of Iraqi citizens, conducted between 22 March and 9 April 2004, found that $71 \%$ of those polled viewed Coalition forces as occupiers, while only $19 \%$ viewed them as liberators. ${ }^{9}$ Along these lines, Diamond (2004: 44) notes that, 'Deep local suspicions of US motives combined with the memory of Western colonialism ... generate a massive lack of legitimacy for the occupation authority.' As such, many Iraqis have responded with resistance to the efforts of the occupiers. This course of action is summed up by an Iraqi tribal leader who told a reporter that the Americans should allow Iraqis to choose their own direction, or 'we will keep resisting until we force them to leave the country' (Quoted in Tyler, 2003).

To further illustrate this point, consider the following array of interactions involving the US occupiers and various groups throughout Iraq. The Kurds fear that they will lose part of their independence and autonomy in the new Iraq. They also fear that they will lose the continued protection of the US. Sunnis are concerned that the occupiers will punish them for their repression of the Shi'a and Kurds. They also fear losing the power they possessed under the Hussein regime. Finally, many Shi'a feel betrayed by the actions of the US during the first

9 The cited poll consisted of face-to-face interviews with 3,444 adults in all parts of Iraq, both urban and rural. The poll was conducted in Arabic and Kurdish by Iraqi interviewers hired and supervised by the Pan Arab Research Center of Dubai. An online version of the poll results is available at http://www.cnn.com/2004/WORLD/meast/04/28/iraq.poll/iraq.poll.4.28.pdf Last accessed 20 April 2008. 
Gulf War (August 1990-February 1991). From the viewpoint of many Shi'a, the US did not provide them with support during their attempt to revolt and take power from the Hussein regime following US military intervention. The revolt ultimately failed and the Hussein regime maintained control of the country until the second Gulf War. As a result, the Shi'a further suffered under Hussein as punishment for the attempted revolt. These relationships become even more complicated when one considers the relationship between the occupiers and the sub-groups within these larger ethnic and religious groups.

Similar to the array of interactions between the indigenous groups and subgroups in Iraq, the past and present interactions between these groups and the occupiers adds an additional layer to the traditional credibility problem. The United States views its occupation of Iraq as an exercise in benevolence. Following the removal of the oppressive Hussein regime, the aim of the occupation is to establish liberal democratic institutions. From the standpoint of the United States, this is a preferable state of affairs. The establishment of such institutions would allow for the protection of the rights and property of Iraqi citizens and for peaceful interaction between Iraqi and American citizens. From an economic standpoint, the peaceful and mutually beneficial exchange that would take place under such institutions would increase the standard of living in Iraq. However, many of the indigenous actors of Iraq view the situation in a drastically different manner as compared to the occupiers.

As mentioned, indigenous Iraqis are involved in a wide array of interactions with other indigenous groups and sub-groups, as well as with the occupiers themselves. These various 'nested games' constrain the ability of foreign occupiers to solve the larger Iraqi 'meta game' (see Coyne, 2006). Stated differently, many indigenous Iraqis view the reconstruction situation, as well as the credible commitment problem within that context, in a fundamentally different fashion than the alien occupiers. What the occupiers view as benevolent and beneficial is often viewed with suspicion by the very people they are attempting to assist.

The situation in Iraq illustrates the often overlooked epistemic aspect of the credible commitment problem. In order to be successful, occupiers must not only overcome the problem of incentives, but also the problem that Iraqis view their proclamations of benevolent reforms as insincere. As Diamond (2004: 43) notes, 'Part of the problem was that [General Jay] Garner and Bremer never comprehended how Iraqis perceived them ...Thus the coalition never grasped, for example, the fact that, although most Iraqis were grateful for having been liberated from a brutal tyranny, their gratitude was mixed with deep suspicion of the United States' real motives (not to mention those of the United Kingdom, a former colonial ruler of Iraq).' The result is that many of the reforms announced by the US lacked credibility in the eyes of Iraqis and have failed to take hold. 
This insight regarding the epistemic aspect of the credible commitment problem can be extended beyond Iraq and generalized to all efforts to exogenously impose institutions. Because occupiers are often trying to impose formal institutional structures that do not necessarily align with the existing informal institutions (e.g., belief systems, values, organizational forms, and so on), the problem of credible commitment is magnified. ${ }^{10}$ The pattern of beliefs in a society is a central factor in the institutions that emerge and sustain over time (North, 1990, 2005; Weingast, 1997). Where occupiers fail to understand the underlying belief systems of indigenous citizens, including how those citizens perceive and interpret the occupiers and the proposed reforms, reconstruction efforts are more likely to fail.

\subsection{Regime uncertainty}

Yet another constraint on finding a solution to the problem of credible commitment in Iraq is the persistence of 'regime uncertainty'. Regime uncertainty refers to a lack of predictability in the rules of the game. When regime uncertainty exists, both indigenous and exogenous actors cannot be confident in the stability of rules over time. Note that the relationship between regime uncertainty and the problem of credible commitment runs in both directions. A lack of credible commitment on the part of policymakers contributes to regime uncertainty, and ongoing regime uncertainty makes it increasingly difficult for policymakers to send a credible signal in future periods. This is because individuals, to some degree, base their decisions in the current period on the past actions of policymakers.

In an earlier sub-section (3.2), we discussed the impact of indigenous divisions on the reconstruction of Iraq. The inability of the various groups and subgroups to bargain toward sustainable institutions is a major cause of regime uncertainty. Given the fragility of institutions, Iraqi citizens and foreigners cannot be confident that agreements and reforms will be stable in future periods.

The attempted reforms and policies of the CPA have contributed to regime uncertainty on several margins. Many of the orders passed by the CPA included the possibility of 'adoption or replacement' by future Iraqi governments. To provide one example of this, consider CPA Order 39. This order calls for the privatization of Iraqi state enterprises and also provides the terms and procedures for making foreign investments in Iraq. Order 39 contains the caveat that the order can be changed or replaced by future Iraqi governments. From the standpoint of potential foreign investors, this creates a situation of regime uncertainty. Stated differently, there is no credible signal that foreign investments will be protected over the long run. For instance, Looney (2004: 94) contends that if Iraqis were given the chance to vote on the issue, they would seek to modify or remove many of the orders issued by the CPA. To the extent this is 
true, neither indigenous Iraqi citizens nor foreigners view reforms as legitimate and credible.

The status of Iraq's sovereignty is yet another aspect contributing to regime uncertainty. A key aspect of the reconstruction, announced by the US government, involves Iraqis engaging in self-determination. In late June 2004, the US announced that it was officially transferring sovereignty to the Iraqi people. However, statements by US officials resulted in confusion around what this transfer actually meant. President Bush announced that it was a transfer of 'full sovereignty' (see Bumiller, 2004). In contrast, a State Undersecretary announced that the transfer was one of 'limited sovereignty' (see White and Weisman, 2004). Secretary of State Colin Powell announced that it was a transfer of sovereignty, but that some of that 'sovereignty they [the Iraqis] are going to allow us to exercise on their behalf..' (quoted in Allen, 2004). These various announcements regarding the extent and nature of sovereignty created regime uncertainty both within and outside Iraq regarding the status of the new Iraq as well as the ongoing role of the US occupiers. On the one hand, officials were indicating that full sovereignty had been transferred to the Iraq people. At the same time, other officials were claiming that sovereignty would be limited (see Weisman, 2004).

The credibility issue associated with sovereignty continues to this day. While the first permanent post-Hussein government of Iraq was established in May 2006, the US occupiers continue to exert major influence over the operations of the country. As mentioned in an earlier section, the presence of the US as a third-party enforcer creates a credibility problem regarding any power-sharing agreement between the various groups of Iraq. In short, there is no way for citizens to know whether the parties to the agreement are truly credible or whether the stability of the agreement is based on the presence of the US forces. Citizens will refuse to fully support and adopt reforms if they believe they will be unenforceable once occupiers exit.

The international dimension also contributes to regime uncertainty in Iraq. While our discussion has mainly focused on the interactions between indigenous Iraqi citizens and between Iraqi citizens and occupiers, in reality the reconstruction is even more complex. The reconstruction of Iraq is not taking place in isolation, but instead is heavily influenced by forces outside of the country. For example, there have been numerous reports of Iran sending financial support as well as weapons to support the insurgency against the occupiers. Further, the role of Iraq's neighbors - Iran, Jordan, Saudi Arabia, Syria, and Turkey - in future periods is unknown to policymakers, occupiers, and Iraqi citizens. What will the governments of these countries do once the reconstruction and occupation ends? Will they support the 'new Iraq' or will they take active steps to undermine the reforms and institutions? Given the uncertainty surrounding the answer to these questions, Iraqi citizens cannot be confident that reforms in the current period will be binding in future periods. 
Even if institutional reforms in Iraq generate some semblance of stability, that progress could be undermined by the actions of other countries in the region. This makes the problem of credible commitment even more complicated. In order to buy into the reforms in Iraq, citizens must be confident that they are binding and will not be undermined be other citizens, the new government of Iraq, and the governments and citizens of neighboring countries. To the extent this confidence is absent or weak, regime uncertainty will persist and reforms will fail to be self-sustaining.

\section{Potential solutions to the credible commitment problem}

Although we focused on examples from the current reconstruction of Iraq, the issues associated with the problem of credible commitment can be generalized, albeit in different forms, to all foreign occupations and attempts to 'export' institutions. Given that the problem of credible commitment is central to any reconstruction effort, the critical issue is understanding potential solutions for sustained cooperation. Several solutions to securing commitment have been discussed in the literature. We consider a few in the context of reconstruction and discuss the conditions under which these solutions are likely to be effective.

A standard solution to the problem of credible commitment is reliance on reputation (see Dixit and Nalebuff, 1991: 144-145; Schelling, 1960: 3543). The underlying logic is that individuals can increase the value of their reputations in future periods by cooperating in the current period. When the value of one's reputation is greater than the benefits from reneging, the result is cooperation. The value of this solution in reconstruction efforts depends on the specific context. In those situations where reputation has generated sustainable cooperation in the pre-occupation period, these reputations may continue to generate cooperation during and after the occupation.

In the Post-World War II occupations of Japan and West Germany, the United States relied on existing institutions and individuals with well-established reputations to implement policy reforms (see Coyne, 2008a: 118-135). For example, in the case of Japan the occupiers used the established position of the emperor to implement many aspects of the reconstruction program. The occupiers also utilized the Diet, the Japanese Parliament, to pass laws as well as to ratify the new Japanese Constitution. Occupiers in West Germany also relied on existing institutions with established credibility. To illustrate this, consider that the Bonn Constitution (i.e., the Basic Law), which was written and adopted during the occupation, drew heavily on the existing Weimar Constitution, a well-established document grounded in indigenous norms and laws. In both Japan and West Germany, the use of institutions with existing reputations as being legitimate overcame many of the issues associated with the problem of credible commitment.

However, where existing reputations do not facilitate cooperation in the preoccupation context, they are unlikely to generate cooperation at the national level 
during and after the occupation. The current reconstruction of Iraq illustrates that where historical divisions create tensions and conflict, existing reputations can prevent bargaining between groups. Further, to the extent that parties from different groups do engage in bargaining, they will often have an incentive to develop a 'tough' reputation to maximize their gains from the negotiation and to set expectations for future negotiations. When parties hold out for a greater share of the future surplus, it is possible that an agreement may not be reached in the current period. This dynamic is evident in Iraq as discussed above. It also applies to other military occupations, such as the mid-1990s US occupation of Somalia, where factionalism made credible commitment to a power-sharing agreement unobtainable.

A related solution is to divide the larger 'game' into smaller sub-games so that the reputation mechanism can operate on a smaller scale. The underlying logic here is that by breaking the larger game into a series of smaller sub-games, reputation may facilitate cooperation within these smaller games. For example, where factions exist, it may be possible to achieve cooperation within a faction but not across factions. The idea of dividing the larger game into smaller subgames underpins many initiatives to incorporate local indigenous leaders into reconstruction efforts.

In the context of reconstruction, there are several potential problems with this solution. First, as noted above, in many conflicts there are not only factions, but also numerous sub-factions within those factions. In some instances, such as Iraq, achieving intra-group coordination is a daunting task with no straightforward solution. A second issue is that the historical aim of many reconstruction efforts has been to export liberal democratic institutions at the national level (see Coyne, 2008a). This requires some cooperative solution to the overarching game involving all groups and factions within the relevant nation. However, as emphasized throughout this paper, the central issue is that citizens must believe that the national government can credibly commit to carry out the stated reforms and perform the announced activities. Absent that credibility, the dynamics of the problem of credible commitment will become evident and efforts to reform national institutions will fail to be sustaining.

Related to this issue, Myerson (2007: 19) notes that there is the real possibility that efforts to work at the local level may be ineffective if local leaders believe that they will not be receive benefits from national leaders in future periods. In such an instance, some form of credibility at the national level is required for local efforts to be effective. A final issue is the ability of local actors to have the necessary resources to make a difference. For example, in the current reconstruction of Iraq, efforts to work with local leaders and local councils have been limited due a lack of power and resources to contribute anything meaningful to the broader reconstruction (see Diamond, 2004: 45).

A third potential solution to the problem of credible commitment is for individuals to adopt a 'tit-for-tat' strategy (see Axelrod, 1984). Under this 
strategy, individuals begin by cooperating and then respond in kind to the decisions made by others. Cooperation will be met with cooperation, and defection will be met with defection. In some cases, adopting the tit-for-tat strategy can generate sustained cooperation. However, the tit-for-tat model does not seem to be at work in past reconstructions. In such a model, individuals cooperate and then only defect if others do so. However, it is difficult to find a case of reconstruction where the parties involved coordinated around cooperative ends only to defect after others did so. The efforts in Afghanistan, Haiti, Iraq, and Somalia, to name a few, are cases where indigenous actors have been unable to initially coordinate around cooperative ends.

In their analysis of the evolution of political institutions, Ferejohn (1991) and Weingast (1997) argue that when multiple equilibria exist, the focal equilibrium will depend on the belief patterns of the citizens regarding the role and nature of government. This argument can be extended beyond political institutions to include economic, legal, and social institutions as well. This indicates that solutions to the problem of credible commitment will be context specific and dependent on the views and beliefs of citizens. As the post-World War II reconstructions of West Germany and Japan indicate, the most effective solution to the problem of credible commitment is reliance on preexisting institutions which have provided credibility prior to the military occupation and reconstruction. These preexisting mechanisms reflect citizen beliefs patterns and are already viewed as legitimate. Where preexisting institutions are absent, occupiers will need to search for alternative means of ensuring credibility. In order to be legitimate, these alternatives must be grounded in the beliefs of the populace. Absent citizen consensus regarding the role and limits of reconstructed institutions, reforms will ultimately fail.

\section{Conclusion}

Our analysis has several implications for efforts to 'export' liberal democratic institutions through military occupation. The first is that successful institutional reforms require a solution to the problem of credible commitment. While this is the most straightforward implication of our analysis, it is also the most difficult to achieve. Where preexisting solutions to the problem of credible commitment do not already exist, traditional mechanisms of self-enforcement may not fill the gap, depending on citizens' belief systems. This is especially important in the context of weak, failed, and conflict-torn states where state institutions are either absent or severely dysfunctional. In these cases, the irony is that reconstruction efforts are least likely to generate sustainable change where they are most needed due to the inability to craft mechanisms that signal credibility and commitment.

A second implication of our analysis is the realization of the epistemic element of institutional change. The problem of credible commitment entails two aspects. 
The first aspect deals with incentives. The second aspect is epistemic and deals with the context within which individuals perceive and interpret the problem of credible commitment. The implication is that finding a solution to the problem of credible commitment requires not just getting the incentives right, but also ensuring the reforms are conducive to the informal institutions (e.g., belief systems, values, and so on). As North (2005) has emphasized, the process of institutional change is grounded in the mental models and belief systems of individuals within a society. It is easier to impose formal institutions than it is to manipulate informal institutions. However, when a disjuncture between the two exists, formal institutions will fail to operate in the desired manner because they will be in conflict with informal institutions.

A final implication of our analysis deals with the viability and limits of reconstruction efforts via military occupation. Reforms in economic, political, and social institutions are a central part of such efforts. However, we have argued that absent a solution to the problem of credible commitment, reforms will fail to take hold. To the extent that mechanisms to ensure credible commitment cannot be established - due to a lack of knowledge of how to design such mechanisms or to the epistemic aspect of the problem - reconstruction efforts should be limited in their goals or entirely curtailed. In the absence of legitimacy and credibility, efforts to exogenously impose institutions have a greater likelihood of generating dysfunctional outcomes or failing altogether.

\section{References}

Acemoglu, D. and S. Johnson (2005), 'Unbundling Institutions', Journal of Political Economy, 115: 949-995.

Acemoglu, D. and J. A. Robinson (2006), Economic Origins of Dictatorship and Democracy, Cambridge: Cambridge University Press.

Acemoglu, D., S. Johnson, and J. Robinson (2001), 'The Colonial Origins of Comparative Development: An Empirical Investigation', American Economic Review, 91: 13691401.

Acemoglu, D., S. Johnson, and J. Robinson (2002), 'Reversal of Fortunes: Geography and Institutions in the Making of the Modern World Income Distribution', Quarterly Journal of Economics, 117: 1231-1294.

Allen, V. (2004), 'Negroponte Says Won't Command Iraqi Government', Reuters, 27 April.

Anderson, L. and G. Stansfield (2004), The Future of Iraq: Dictatorship, Democracy or Division?, New York: Palgrave McMillian.

Aoki, M. (2001), Toward a Comparative Institutional Analysis, Cambridge, MA: MIT Press.

Aoki, M. (2007), 'Endogenizing Institutions and Institutional Changes', Journal of Institutional Economics, 3(1): 1-31.

Axelrod, R. (1984), The Evolution of Cooperation, New York: Basic Books.

Baker, J. A. and L. H. Hamilton (2006), The Iraq Study Group Report, New York: Vintage Books.

Boettke, P. J. (1993), Why Perestroika Failed: The Politics and Economics of Socialist Transformation, New York: Routledge. 
Boettke, P. J. (2001), 'Credibility, Commitment, and Society Economic Reform', in P. J. Boettke (ed.), Calculation and Coordination, New York: Routledge, pp. 154175.

Boettke, P. J., C. J. Coyne, and P. T. Leeson (forthcoming), 'Institutional Stickiness and the New Development Economics', American Journal of Economics and Sociology.

Bumiller, E. (2004), 'Bush lays out goals for Iraq: self-rule and stability', New York Times, 25 May, A1.

Cowen, T. and C. J. Coyne (2005), 'Postwar Reconstruction: Some Insights from Public Choice and Institutional Economics', Constitutional Political Economy, 16: 31-48.

Coyne, C. J. (2006), 'Reconstructing Weak and Failed States: Foreign Intervention and the Nirvana Fallacy', Foreign Policy Analysis, 2: 343-361.

Coyne, C. J. (2008a), After War: The Political Economy of Exporting Democracy, Stanford, CA: Stanford University Press.

Coyne, C. J. (2008b), ‘The Politics of Bureaucracy and the Failure of Reconstruction', Public Choice, 135(1-2): 11-22.

Crocker, B. (2004), 'Reconstructing Iraq's Economy', The Washington Quarterly, 27(4): 7393.

Diamond, L. (2004), 'What Went Wrong in Iraq?', Foreign Affairs, 83(5): 34-56.

Dixit, A. and B. Nalebuff (1991), Thinking Strategically, New York: Norton.

Fearon, J. D. (2007), 'Iraq's Civil War', Foreign Affairs, 86(2): 2-15.

Ferejohn, J. (1991), 'Rationality and Interpretation: Parliamentary Elections in Early Stuart England', in K. Monroe (ed.), The Economic Approach to Politics, New York: Harper Collins, pp. 279-305.

Flores, T. E. and I. Nooruddin (2007), 'Democracy Under the Gun: Understanding PostConflict Economic Recovery’, mimeo, Department of Political Science, University of Michigan and Ohio State University.

Foote, C., W. Block, K. Crane, and S. Gray (2004), 'Economic Policy and Prospects in Iraq', Journal of Economic Perspectives, 18(3): 47-70.

Fukuyama, F. (2004), State-Building: Governance and World Order in the 21st Century, Ithaca: Cornell University Press.

Fukuyama F. (ed.) (2005), Nation-Building: Beyond Afghanistan and Iraq, Maryland: The Johns Hopkins University Press.

Gehlbach, S. and P. Keefer (2008), 'Investment Without Democracy: Ruling-Party Institutionalization and Credible Commitment in Autocracies', mimeo, Department of Political Science, University of Wisconsin, Madison.

Hartzell, C. and M. Hoodie (2007), Crafting Peace: Power Sharing and the Negotiated Settlement of Civil Wars, Pennsylvania: Penn State University.

Keefer, P. (2007), 'Insurgency and Credible Commitment in Autocracies and Democracies', World Bank Policy Research Working Paper 4185.

Keefer, P. and R.Vlaicu (2005), 'Democracy, Credibility and Clientelism', World Bank Policy Research Working Paper 3472.

King, Jr., N. (2003), 'Bush Officials Devise a Broad Plan For Free-Market Economy in Iraq', The Wall Street Journal, 1 May, A1.

Klein, D. (1990), 'The Macroeconomic Foundations of Rules versus Discretion', Constitutional Political Economy, 1(3): 1-19.

Kofford, K. J. (2003), 'Iraq and public choice', Eastern Economic Journal, 29(4): 619-621.

Kurrild-Klitgaard, P. (2004), 'Blood, Baath and Beyond: the Constitutional Dilemma of Iraq', Public Choice, 119(1-2): 13-30. 
Kydd, A. and B. F. Walter (2002), 'Sabotaging the Peace: The Politics of Extremist Violence', International Organization, 56(2): 263-296.

Kydland, F. E. and E. Prescott (1977), 'Rules Rather than Discretion: The Inconsistency of Optimal Plans', Journal of Political Economy, 85(3): 473-491.

Looney, R. (2004), 'The Viability of Economic Shock Therapy in Iraq', Challenge, 47(5): 86-103.

Myerson, R. B. (2007), 'Foundations of the State in Theory and Practice: Reading Bremer and the Counterinsurgency Field Manual', mimeo, Department of Economics, University of Chicago.

Nooruddin, I. and T. E. Flores (2008), 'Financing the Peace: Evaluating World Bank Post Conflict Assistance Programs', mimeo, Department of Political Science, The Ohio State University and University of Michigan.

North, D. C. (1990), Institutions, Institutional Change, and Economic Performance, Cambridge: Cambridge University Press.

North, D. C. (1993), 'Institutions and Credible Commitment', Journal of Institutional and Theoretical Economics, 149(1): 11-23.

North, D. C. (2005), Understanding the Process of Economic Change, Princeton: Princeton University Press.

Payne, J. L. (2006), 'Does Nation Building Work?', The Independent Review, 10(4): 599-610.

Peceny, M. (1999), Democracy at the Point of Bayonets, University Park: The Penn State University Press.

Persson, T. and G. Tabelline (2000), Political Economics: Explaining Public Policy, Cambridge, MA: MIT Press.

Rodrik, D., A. Subramanian and F. Trebbi (2004), 'Institutions Rule: The Primacy of Institutions Over Geography and Integration in Economic Development', Journal of Economic Growth, 9: 131-165.

Roeder P. and D. Rothchild (eds) (2005), Sustainable Peace: Power and Democracy after Civil Wars, Ithaca: Cornell University Press.

Sanger, D. E. (2003), 'America's Gamble: A Quick exit Plan for Iraq', New York Times, 16 November, A17.

Schelling, T. (1960), The Strategy of Conflict, Cambridge, MA: Harvard University Press.

Stiglitz, J. and Bilmes L (2008), The Three Trillion Dollar War: The True Cost of the Iraq Conflict, New York: W. W. Norton.

Tullock, G. (1985), 'Adam Smith and the Prisoner's Dilemma', The Quarterly Journal of Economics, 100: 1073-1081.

Tyler, P. E. (2003), 'Three Wars over Iraq: Staying the Course May Be the Hardest Battle', New York Times, 5 October, Section 4, Column 1, Week in Review Desk, p. 1.

Weingast, B. R. (1997), 'The Political Foundations of Democracy and the Rule of Law', American Political Science Review, 91: 245-263.

Weisman, S. R. (2004), 'The Struggle for Iraq: Politics; White House Says Iraq Sovereignty Could be Limited', New York Times, 23 April, A1.

White, J. and J. Weisman (2004), 'Limited Iraqi Sovereignty Planned', Washington Post, 22 April, A25.

World Bank (2006), 'Rebuilding Iraq: Economic Transition and Reform', February. Available at: http://siteresources.worldbank.org/IRFFI/Resources/IraqCEM-finalComplete.pdf. 